\title{
7-Chloro-6-piperidin-1-yl-quinoline-5,8-dione (PT-262), a novel synthetic compound induces lung carcinoma cell death associated with inhibiting ERK and CDC2 phosphorylation via a p53-independent pathway
}

Tzu-Sheng Hsu $\cdot$ Chinpiao Chen $\cdot$ Pei-Ting Lee $\cdot$

Shu-Jun Chiu · Huei-Fang Liu · Chih-Chien Tsai • Jui-I Chao

Published online: 12 March 2008

(C) Springer-Verlag 2008

Erratum to: Cancer Chemother Pharmacol DOI 10.1007/s00280-007-0667-5

In Fig. I, the chemical structures of compound 3, 4, and 7 were incorrect. The corrected structures are shown below:

compound 3 (PT-262):<smiles>O=C1C(N2CCCCC2)=C(Cl)C(=O)c2ncccc21</smiles>

3 compound 4:<smiles>O=c1c2ccccc2[nH]c2sc3ccccc3c(=O)c12</smiles>

compound 7:<smiles>O=C1C(Cl)=C(NCCN2CCOCC2)C(=O)c2ccccc21</smiles>

The online version of the original article can be found under doi:10.1007/s00280-007-0667-5.

T.-S. Hsu · H.-F. Liu · C.-C. Tsai · J.-I. Chao $(\bowtie)$ Institute of Pharmacology and Toxicology,

Tzu Chi University, 701, Section 3, Chung-Yang Road,

Hualien 970, Taiwan

e-mail: chaoji@mail.tcu.edu.tw

C. Chen · P.-T. Lee

Department of Chemistry,

National Dong Hwa University, Hualien, Taiwan

S.-J. Chiu

Department of Life Science, Tzu Chi University,

Hualien, Taiwan 